\title{
Reference P-wave velocity in coal seams at great depths in Jastrzebie coal mine
}

\author{
Jakub Kokowski ${ }^{1, *}$, Zbigniew Szreder $^{2}$, and Elżbieta Pilecka $^{3}$ \\ ${ }^{1}$ Mineral and Energy Economy Research Institute of the Polish Academy of Sciences, Cracow, \\ Poland \\ ${ }^{2}$ JSW S.A. KWK "Budryk", Ornontowice, Poland \\ ${ }^{3}$ Cracow University of Technology, Cracow, Poland
}

\begin{abstract}
In the study, the determining of the reference velocity of the Pwave in coal seams used in seismic profiling to assess increases and decreases in relative stresses at large depths has been presented. The seismic profiling method proposed by Dubinski in 1989 covers a range of depth up to $970 \mathrm{~m}$. At present, coal seams exploitation in Polish coal mines is conducted at greater depths, even exceeding $1200 \mathrm{~m}$, which creates the necessity for a new reference velocity model. The study presents an empirical mathematical model of the change of the P-wave velocity in coal seams in the geological conditions of the Jastrzebie coal mine. A power model analogous to the Dubinski's one was elaborated with new constants. The calculations included the results from 35 measurements of seismic profiling carried out in various coal seams of the Jastrzebie mine at depths from 640 to $1200 \mathrm{~m}$. The results obtained cause changes in the result of calculations of seismic anomalies. Future validation of the proposed model with larger data set will be required.
\end{abstract}

Key words: rock burst hazard, Dubinski method, seismic profiling, refracted P-wave

\section{Introduction}

In Polish hard coal mines, the Dubinski's seismic profiling method [1-2] is often used to assess the rock burst hazard. This method is based on measurement of the refracted P-wave velocity in the coal seam. The measured velocity changes depend on the stress-strain state, which has a significant impact on the rock burst hazard [3-5].

Seismic anomaly is calculated as a ratio of measured P-wave velocities to the so-called reference velocity for depth of the survey. This velocity was statistically calculated based on the results of several hundred seismic measurements in depth range $190-970 \mathrm{~m}$ [1]. Due to the development of coal seam exploitation at ever greater depths, even exceeding $1200 \mathrm{~m}$, and an increasing threat of the rock bursts [6], there is a need to verify the formula of the reference velocity as a function of depth.

The seismic profiling method was used to solve many research tasks related to the exploitation of coal seams in rock burst hazard conditions. Tor et al. [7] presented an example of using the method to assess the effectiveness of destressing blasting in the Jas-Mos hard

\footnotetext{
*Corresponding author: kokowski@min-pan.krakow.pl
} 
coal mine. Research has allowed to identify zones requiring implementation of preventive measures.

Seismic profiling was conducted for the use of the damping factor as an additional seismic parameter [8-11]. Pilecki and Klosinski [8] came to the conclusion that the damping factor is more sensitive to the changes of stress in the rock mass compared to indication based on velocity of the P-wave. This result was confirmed by Wojtecki and Dzik [11].

Interesting study was conducted by Olechowski et al. [12] who compared the results of seismic profiling with the results of the WAS-96/RMS method [13]. They concluded that the seismic profiling method provides more reliable results. In addition, seismic profiling results are continuous as opposed to discrete results of the WAS-96/RMS method. It should be emphasized, however, that the WAS-96/RMS method is very useful in assessing rock burst hazard in a heading face zone.

Szreder and Barnas [14] reported that "seismic profiling in underground excavations was also carried out for different purposes in other geological conditions for example: in a salt body to estimate the width of the fracture zone in the side-walls of excavations [15] and also in tunneling [16-17]"

The aim of this study is to modify the Dubinski's formula [1] for calculation the reference velocity of P-wave in coal seams for its applicability at greater depths below $1000 \mathrm{~m}$ in the geological conditions of Jastrzebie coal mine. The calculations of the modified formula took into account 35 new values of P-wave velocity measured at a depth of 900 to $1200 \mathrm{~m}$. The introductory part of the article presents the theoretical foundations of the seismic profiling method. Then geological conditions in Jastrzebie coal mine have been described. The main part of the study presents the assumptions for calculating the reference velocity formula, the results of statistical calculations and their analysis. coal mine

\section{Theoretical background of seismic profiling in coal seams}

The velocity of refracted $\mathrm{P}$-wave in coal seam is the basic parameter calculated from seismic profiling in Dubinski method [1]. This is the velocity of a wave propagating along an excavation in an elastic zone (not disturbed by excavation) on the border with a plastic zone (disturbed by excavation). The border between elastic and plastic zones may be illustrated by the use of a Ladanyi model (fig.1).

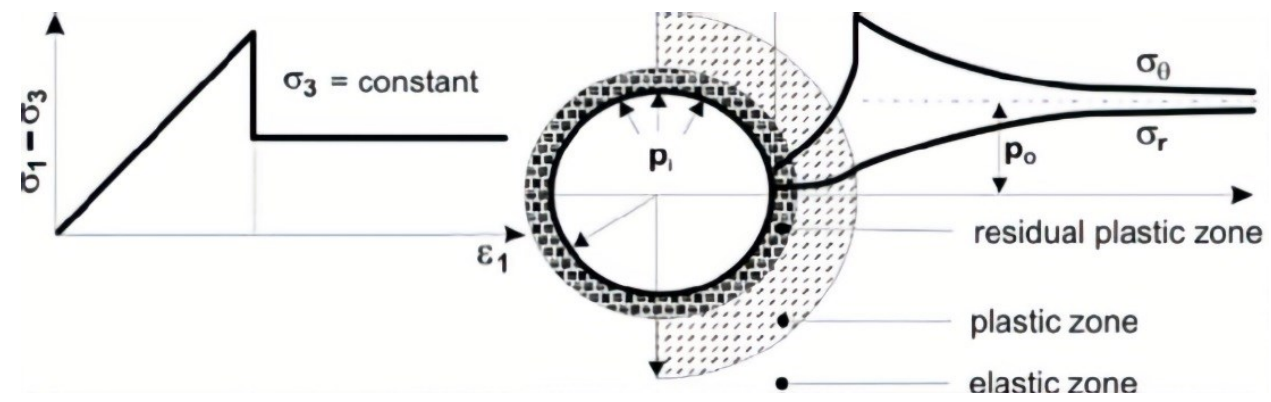

Fig. 1. Model of behaviour of a rock mass around an excavation ([9] on the basis of [18]) $\sigma_{1}-$ major principal stress, $\sigma_{3}$-minor principal stress, $\sigma_{\theta}$ - tangential stress, $\sigma_{r}$ - radial stress, $\varepsilon_{1}$ - major principal strain, $p_{o}$ - virgin stress, $p_{i}$ - lining load.

In practice, the interpretation of the refracted P-wave is not easy, because this border is transient. An additional problem is related to the fact that the velocity of the determined Pwave does not differ significantly from the velocity of the refracted S-wave in shale layers in the roof and the bottom of the coal seam (Fig. 2) [14]. At greater distances from the excitation 
point, the first breaks of the refracted P-wave in shale layers overtakes or distorts the first breaks of the $\mathrm{P}$-wave in the coal seam.

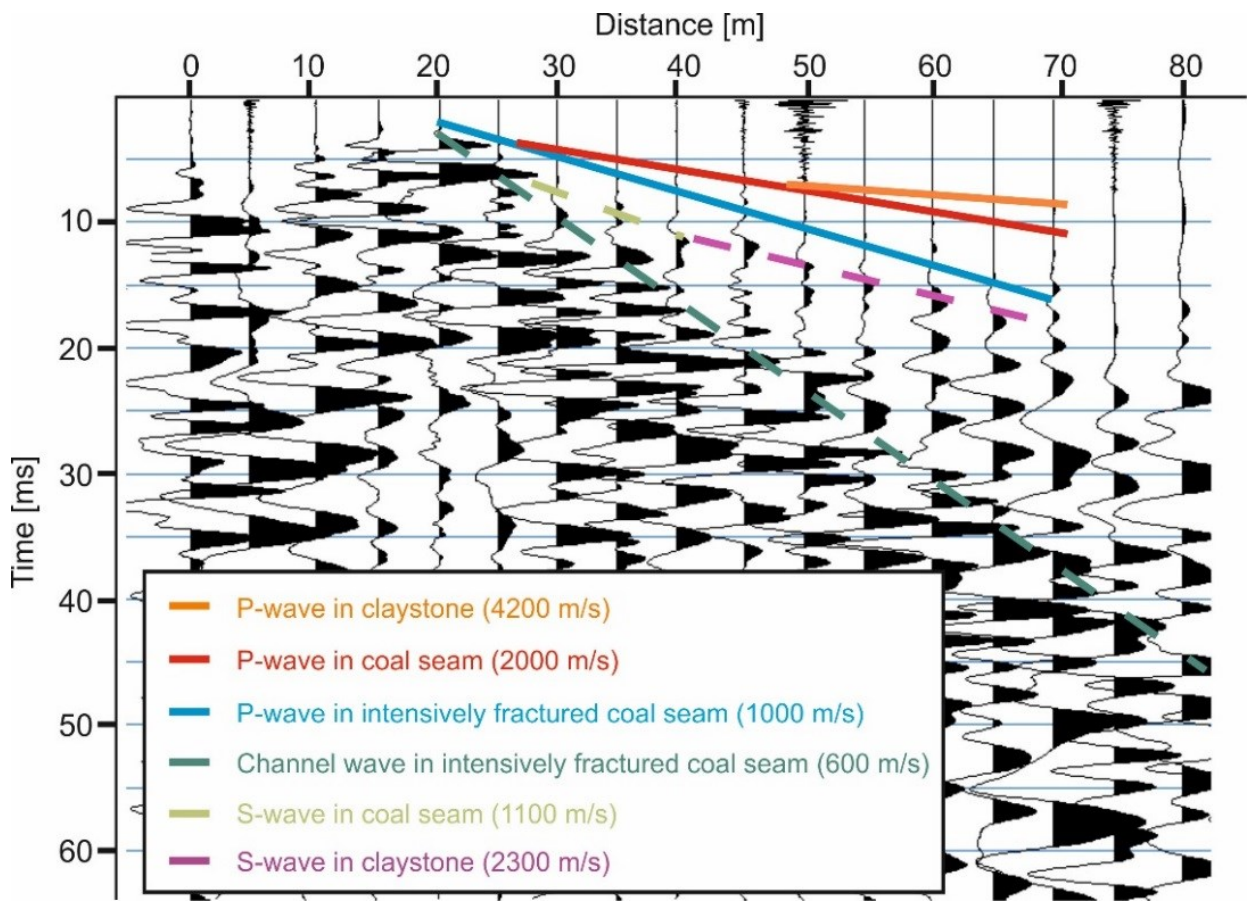

Fig. 2. Seismogram with selected P- waves, S-waves and the channel wave.

Comparison of the measured $\mathrm{V}_{\mathrm{P}}$ velocity with the reference velocity $\mathrm{V}_{0}$ for a given depth allows for calculation of the seismic anomaly according to the formula [2]:

$$
A=\frac{V_{P}-V_{0}}{V_{0}} \cdot 100[\%]
$$

The calculated seismic anomaly (fig. 3) is used for assessment of probable increase or decrease in relative stress (tab. 1).

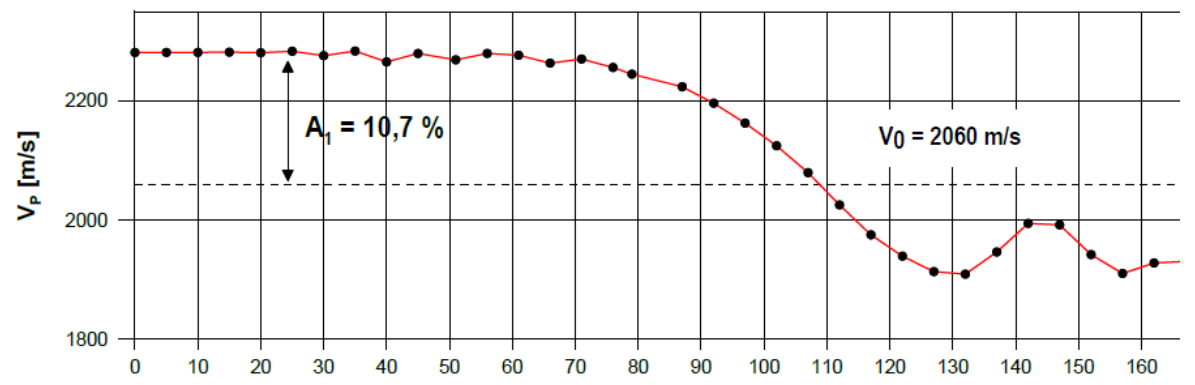

Fig. 3. An example of the results of seismic profiling at a depth of about $900 \mathrm{~m}$ in "Borynia-ZofiowkaJastrzebie" Hard Coal Mine with the reference velocity $\mathrm{V}_{0}$ (dashed line) and the anomaly $\mathrm{A}_{1}$ marked [19].

The empirical formula for the reference velocity $\mathrm{V}_{0}$ was determined on the basis of laboratory tests and several hundred seismic measurements carried out in the Upper Silesian Coal Basin hard coal mines (39 mines, 292 measurements) in 190-970 m depth range [1]: 


$$
V_{0}=1200+4.83 h^{0.76}
$$

where $h$ is the depth of the measurement site.

Table 1. Seismic scale of relative stress changes in Upper Silesian Coal Basin conditions for depth range $500-900 \mathrm{~m} \mathrm{[2].}$

\begin{tabular}{|c|c|c|c|}
\hline $\begin{array}{c}\text { Degree of } \\
\text { relative stress } \\
\text { increase } \\
\text { (decrease) }\end{array}$ & $\begin{array}{c}\text { Positive (negative) } \\
\text { seismic anomaly [\%] }\end{array}$ & $\begin{array}{c}\text { Scale of relative } \\
\text { stress increase } \\
\text { (decrease) }\end{array}$ & $\begin{array}{c}\text { Probable increase (decrease) } \\
\text { in relative stress } \\
{[\%]}\end{array}$ \\
\hline 0 & $<5(>-7.5)$ & Lack/ very low & $<20(<25)$ \\
\hline 1 & $5-15(-7.5 \div-15)$ & Low & $20-60(25 \div 55)$ \\
\hline 2 & $15-25(-15 \div-25)$ & Medium & $60-140(55 \div 80)$ \\
\hline 3 & $>25(<-25)$ & High & $>140(>80)$ \\
\hline
\end{tabular}

\section{Geological and mining conditions in the research area in Jastrzebie coal mine}

The Jastrzebie coal mine is located in the southwestern part of the Upper Silesian Coal Basin east of the Orlowo overlap. The Jastrzebie mining area is bordered on the west by the Radlin mining area coinciding with the overlap border (disturbance) of the Orlowo-Boguszowice region, on the north by the Borynia mining area, on the east by the Zofiowka mining area, and on the south by the closed Moszczenica mining area (Fig. 4).

The main geological element in this area is the Jastrzebie anticline running from NE to SW, also called the Mszana-Jastrzebie saddle [20]. The coal deposit is dominated by folded tectonics. The faults located in the Jastrzebie coal mine area have small throws (up to 30 meters) [21].

The Jastrzebie mining area consists of Quaternary, Neogene (Miocene) and Upper Carboniferous (productive) formations. The top of Upper Carboniferous deposits in the Jastrzebie mining area lie directly under Neogene and Quaternary formations at a depth of 60 to $150 \mathrm{~m}$ [21]. They are represented by conglomerates, sandstones, mudstones and claystones with numerous hard coal seams of varying thickness from a few centimeters to about 9 meters. Carboniferous deposits are developed as Ruda beds (group 400), Saddle beds (group 500) and Poreba beds (group 600).

Seismic profiling measurements were carried out in coal seams located in Saddle beds. These beds consist mainly of sandstone formations. They also contain mudstones and claystones, which usually accompany coal seams. The thickness of the beds is $240-290 \mathrm{~m}$. It was found that the 501, 502 and 503 coal seams are separated by $5-15 \mathrm{~m}$ sandstone layers, 504 coal seam $(0.5-3 \mathrm{~m})$ lies between sandstone and shales series and 505 and $506(1.5-3.5 \mathrm{~m})$ coal seams are often combined. The 510 coal seam reaches the greatest thicknes of $4-5 \mathrm{~m}$ [21].

In the tested coal seams of saddle beds, the uniaxial compressive strength of coal $\mathrm{Rc}=4.2$ 19.4 $\mathrm{MPa}$ and bulk density $\gamma_{0}=12.5-13.4 \mathrm{kN} / \mathrm{m}^{3}$ (MEERI PAS reports). 


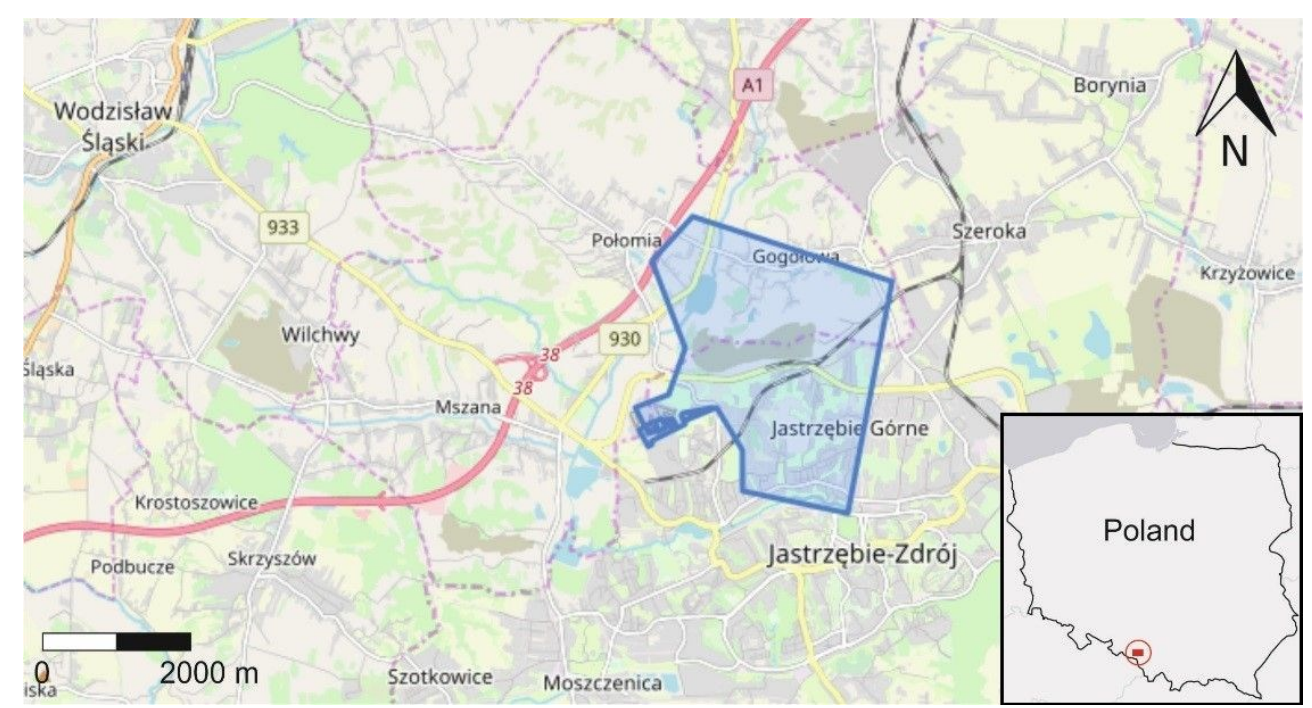

Fig. 4. Location of the Jastrzebie mining area (borders marked in blue), (source: Geoportal GeoLOG).

\section{The reference velocity formula calculation methodology}

In order to determine the modified Dubinski's formula [1], the following calculation methodology was used:

1. For reference velocity calculations, all archival values (246) from Dubinski's dataset [1] and additional values (35) measured by MEERI PAS team at depths 640-1200 $\mathrm{m}$ in coal seams: 505/2, 510/1, 510/1lg, 510/2, 510/2ld were used. The MEERI PAS team performed the research in the years 2006-2019. In total, 281 values were analyzed.

2. It was assumed that the reference velocity $\mathrm{V}_{0}$ changes with the depth $\mathrm{h}$ according to the mathematical model determined by Dubinski [1]: $\mathrm{V}_{0}=1200+\mathrm{a} h^{\mathrm{b}}$.

3. Based on the regression analysis, only velocity values less than double the standard deviation $\sigma$ were used for further calculations:

$$
\sigma=\sqrt{\frac{\sum_{\mathrm{i}=1}^{\mathrm{n}}\left(\mathrm{y}_{\mathrm{i}}-\widehat{\mathrm{y}_{1}}\right)^{2}}{\mathrm{n}}}
$$

where: $\widehat{y l}$ - the theoretical values calculated from the regression model, $y_{i}$ - the measured values and $n$ - the number of measured values.

4. New coefficients were calculated for the power model $\mathrm{V}_{0}=1200+\mathrm{a} h^{\mathrm{b}}$ along with the error assessment based on the coefficient of determination $\mathrm{R}^{2}$ :

$$
R^{2}=\frac{\sum_{i=1}^{n}\left(\hat{y}_{i}-\bar{y}\right)^{2}}{\sum_{i=1}^{n}\left(y_{i}-\bar{y}\right)^{2}}
$$

where: $\bar{y}$ - arithmetic mean of empirical values of the explained variable.

The velocities from seismic profiling measurements were determined from the sections of the profile, the least disturbed by mining and geological factors, i.e. the influence of faults, longwall and heading faces, edges of adjacent, exploited seams and etc. Despite these efforts, the choice of measurement sites may influence on calculations of reference velocity. 


\section{The results of calculations and their analysis}

Table 2 summarizes the information on the set of archival data [1] and new data obtained from seismic profiling in the Jastrzebie coal mine in the years 2006-2019.

Table 2. Characterization of the dataset used for calculations.

\begin{tabular}{|c|c|c|}
\hline \multirow{2}{*}{ Parameter } & \multicolumn{2}{|c|}{ Dataset } \\
\cline { 2 - 3 } & Jastrzebie dataset & $\begin{array}{c}\text { Dubinski archival } \\
\text { data }\end{array}$ \\
\hline Number of velocity values & 25 & 245 \\
\hline Coefficient of determination $\mathrm{R}^{2}$ & 0.69 & 0.81 \\
\hline Minimum depth $[\mathrm{m}]$ & 670 & 190 \\
\hline Maximum depth $[\mathrm{m}]$ & 1200 & 970 \\
\hline Minimum P-wave velocity $[\mathrm{m} / \mathrm{s}]$ & 1900 & 1500 \\
\hline Maximum P-wave velocity $[\mathrm{m} / \mathrm{s}]$ & 2330 & 2200 \\
\hline Average P-wave velocity $[\mathrm{m} / \mathrm{s}]$ & 2095 & 1870 \\
\hline
\end{tabular}

From all 281 velocity values, those that were greater than double the standard deviation $(\sigma=155 \mathrm{~m} / \mathrm{s})$ were rejected. As a result, 25 velocity values from the Jastrzebie coal mine and 245 velocities from the archival collection were used for the calculations, which in total gave 270 values (Fig. 5).

The range of velocity values from the Jastrzebie coal mine is $1900-2330 \mathrm{~m} / \mathrm{s}$, with the average velocity of $2095 \mathrm{~m} / \mathrm{s}$ and standard deviation $120 \mathrm{~m} / \mathrm{s}$, whereas the range of the archival dataset is $1500-2200 \mathrm{~m} / \mathrm{s}$, with the average velocity of $1870 \mathrm{~m} / \mathrm{s}$, and the standard deviation $134 \mathrm{~m} / \mathrm{s}$ (Tab. 2). The dataset from Jastrzebie coal mine was characterized by noticeably higher velocity values compared to the archival dataset. This difference is related to the greater average depth of measurement in Jastrzebie coal mine, but also to the possible influence of various geological and mining factors.

The results of the regression analysis are presented in Table 3. As a result of the calculations for the conditions of Jastrzebie coal mine we propose the following modified Dubinski's formula:

$$
\mathrm{V}_{0}=1200+2.73 h^{0.85}
$$

The $\mathrm{R}^{2}$ determination coefficient for the modified model was 0.82 , while the standard deviation $\sigma$ was equal to $63 \mathrm{~m} / \mathrm{s}$. Figure 6 presents Dubinski's general model and our formula for the conditions of Jastrzebie coal mine. Both models do not differ significantly. The Jastrzebie coal mine model is more similar to a linear model than the general model of Dubinski. In addition, the Jastrzebie coal mine plot is within the data range (200 - $1200 \mathrm{~m})$ in the regression range of the linear plot for the $95 \%$ confidence interval. It was noticed that the linear model with the form $\mathrm{V}_{0}=1300+0.88 \mathrm{~h}$ has the same coefficient of determination $(0.82)$ and standard deviation $(63 \mathrm{~m} / \mathrm{s})$ as the power model of Jastrzebie coal mine.

The difference between Dubinski's formula and the new Jastrzebie coal mine formula is close to zero for a depth of $600 \mathrm{~m}$, and then it increases with depth: for $900 \mathrm{~m}$ it has $\sim 35 \mathrm{~m} / \mathrm{s}$ and for $1200 \mathrm{~m}$ it has $\sim 75 \mathrm{~m} / \mathrm{s}$.

It should be noted that the Jastrzebie coal mine formula still needs verification after collecting more data below a depth of about $1100 \mathrm{~m}$. 


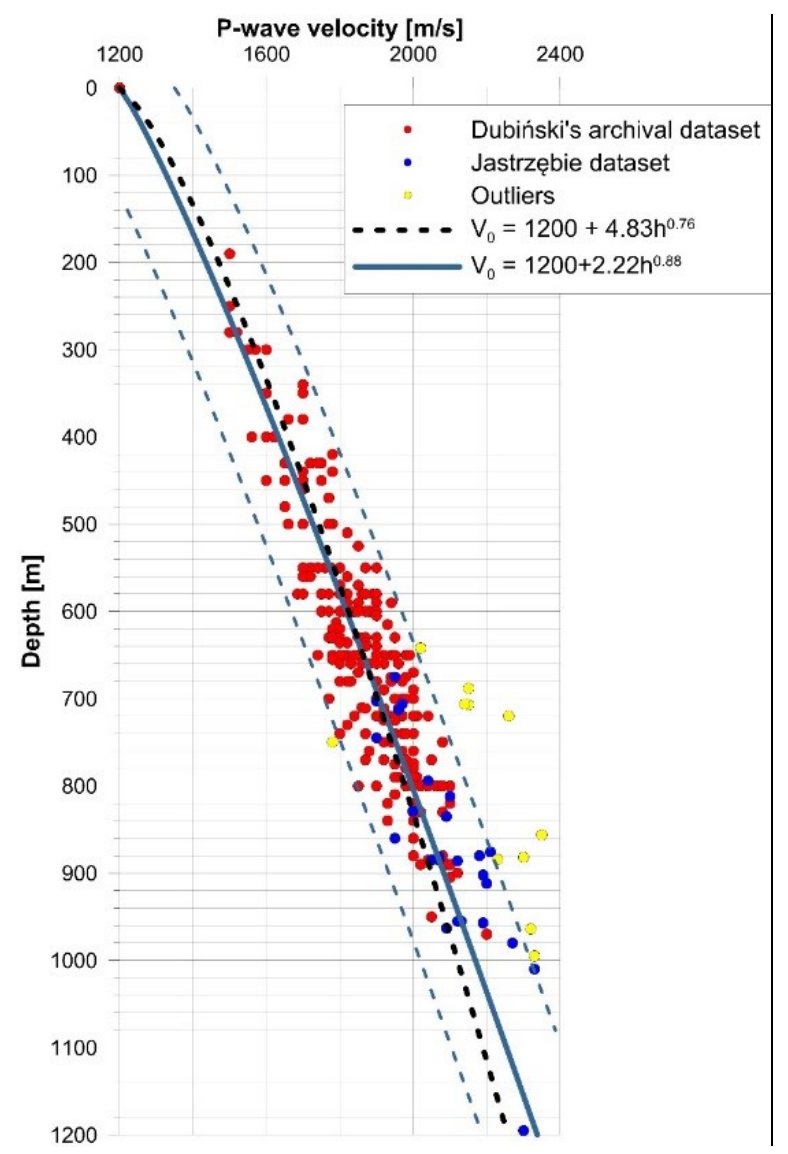

Fig. 5. The plot of archival dataset (red points) and new dataset from Jastrzebie coal mine (blue points) together with the regression curve for all data (blue line) and the general Dubinski's formula (dashed black line). Outliers are marked in yellow.

Table 3. Determination coefficients $\mathrm{R}^{2}$ and standard deviation $\sigma$ for the Dubinski's formula and Jastrzebie coal mine formula.

\begin{tabular}{|c|c|c|c|}
\hline \multicolumn{2}{|c|}{ Reference velocity model } & $\begin{array}{c}\text { Coefficient of } \\
\text { determination } \mathbf{R}^{2}\end{array}$ & $\begin{array}{c}\text { Standard } \\
\text { deviation } \\
\sigma\end{array}$ \\
\hline $\begin{array}{c}\text { Dubinski's formula } \\
\text { (Archival dataset) }\end{array}$ & $\mathrm{V}_{0}=1200+4.83 h^{0.76}$ & 0.77 & 64 \\
\hline $\begin{array}{c}\text { Jastrzebie coal mine formula } \\
\text { (Archival and Jastrzebie } \\
\text { dataset) }\end{array}$ & $\mathrm{V}_{0}=1200+2.73 h^{0.85}$ & 0.82 & 63 \\
\hline
\end{tabular}




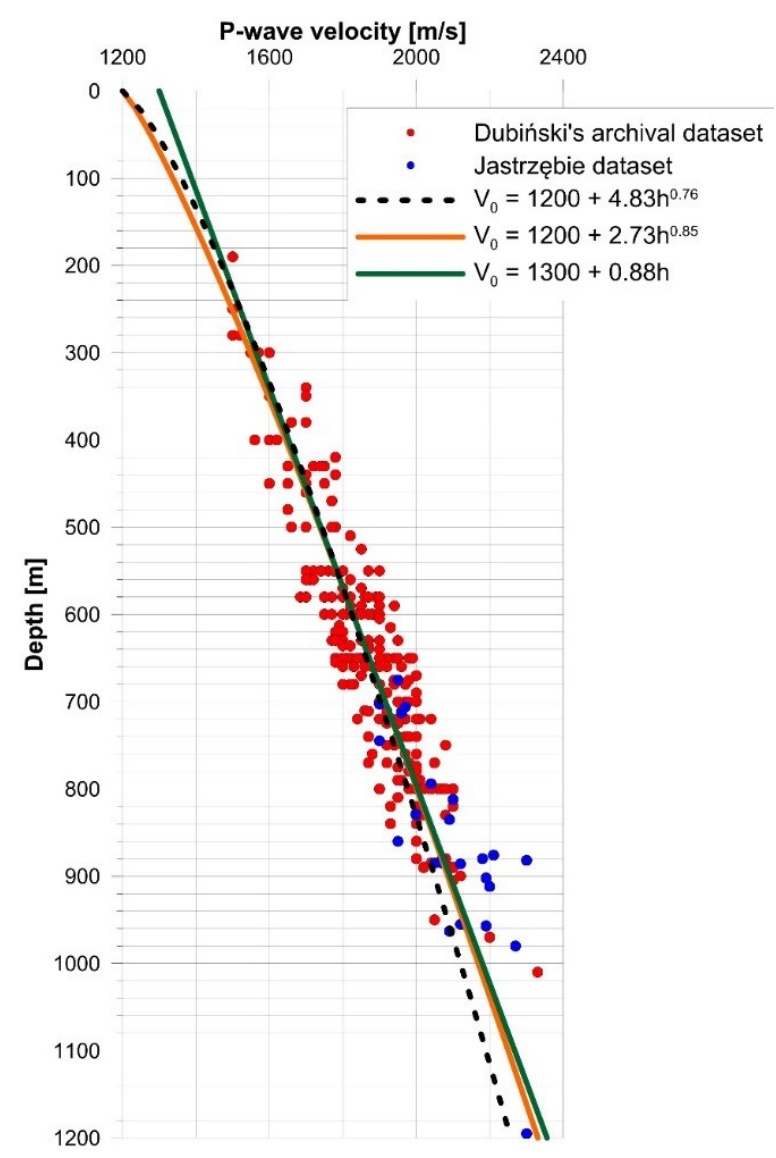

Fig. 6. The plot of the Dubinski model, and the Jastrzebie coal mine power and linear model.

\section{Resume}

Dubinski's formula [1] for calculating the reference P-wave velocity in coal seams depending on the depth was determined for maximum depth of $970 \mathrm{~m}$. Currently, coal seams are mined at greater depths, even exceeding $1200 \mathrm{~m}$. Therefore, there is a need to adapt this formula to greater depths. In the study we modified Dubinski's formula by taking into account additional 35 reference velocity values measured in the geological and mining conditions of the Jastrzebie coal mine within the depth range of 640-1200 m. Based on the calculations made, the following conclusions were drawn:

1. The dataset from Jastrzebie coal mine differs from the Dubinski's dataset for the depths below $900 \mathrm{~m}$. P-wave velocities values are much higher than it would result from the Dubinski model. Therefore, an attempt to calculate the formula taking into account new dataset was found to be justified.

2. As a result of statistical calculations for the geological and mining conditions of Jastrzebie coal mine a power formula is proposed in the following form: $\mathrm{V}_{\mathrm{P}}=1200+2.73 h^{0.85}$.

3. After obtaining more data, especially from a depth below $1100 \mathrm{~m}$, the formula should be recalculated. 


\section{References}

1. J. Dubinski, Sejsmiczna metoda wyprzedzajacej oceny zagrozenia wstrzasami gorniczymi w kopalniach wegla kamiennego (Seismic method of shock hazard assessment in hard coal mines), Central Mining Institute (1989) (in Polish)

2. J. Dubinski, W. Konopko, Tapania - ocena, prognoza, zwalczanie ( Rock bursts assessment, prognosis, defeating) Wyd. GIG, Katowice (2000) (in Polish)

3. Z. Pilecki, Dynamic analysis of mining tremor impact on excavation, Proc. Int. FLAC Symp. on Numerical Modeling in Geomechanics, Detournay \& Hart, 397-400 (1999)

4. J. Dubinski, Z. Pilecki, W. Zuberek, Badania geofizyczne w kopalniach-przeszlosc, terazniejszosc, i zamierzenia na przyszlosc (Geophysical research in mines - past, present and future plans), MEERI PAS, Krakow (2001) (in Polish)

5. Z. Burtan, A. Zorychta, J. Cieslik, D. Chlebowski D., Arch Min Sci 59 (3) 691-704 (2014) doi: 10.2478/amsc-2014-0048

6. G. Mutke, J. Dubinski, A. Lurka New criteria to assess seismic and rock burst hazard in coal mines, Arch Min Sci 60 (3) 743-760 (2015) doi: 10.1515/amsc-2015-0049

7. A. Tor, P. Chmiel, Z. Pilecki, A. Jakubow, R. Skatula, Z. Szreder, J. Klosinski, Kontrola efektywnosci strzelan torpedujacych za pomoca profilowan sejsmicznych (Control of the effectiveness of torpedo blastings using seismic profiling), Bezpieczeństwo Pracy i Ochrona Środowiska w Górnictwie, Miesięcznik WUG 142 (6) 62-64 (2006) (in Polish)

8. Z. Pilecki, J. Klosinski, Profilowanie tlumienia fali sejsmicznej w pokladzie wegla (Profiling of seismic wave attenuation in a coal seam), Bezp. Pracy i Ochrona Srod. w Gornictwie, Materialy Warsztatów, 381-393 (2007) (in Polish)

9. Z. Szreder, Z. Pilecki, J. Klosinski, Efektywnosc rozpoznania oddzialywania krawedzi eksploatacyjnych metodami profilowania tlumienia oraz predkosci fali sejsmicznej (Effectiveness of recognition of the impact of exploaition edges by methods of seismic wave attenuation and velocity profiling), Gospod Surow Min 24 (2/3) (2008) (in Polish)

10. Z. Szreder, Z. Pilecki, J. Klosinski, Comparison of Profiling Results of Attenuation and Velocity of Refracted P-wave in Coal-seam, Proc. 14th EAGE European Meeting of Environmental and Engineering Geophysics (2008) doi: 10.3997/2214-4609.20146265

11. L. Wojtecki, G. Dzik, Profilowanie sejsmiczne ociosow chodnikow weglowych w wersji kinematycznej $i$ tlumieniowej (Seismic profiling along sidewalls in the kinematic and attenuation versions) Mine Mechanization and Automation 50(4) 29-37 (2012) (in Polish)

12. S. Olechowski, K. Krawiec, J. Kokowski, Z. Szreder, P. Harba, M. Cwiekala, Comparison of the results of the seismic profiling and WAS-96/RMS seismoacoustic active method in an assessment of the impact of the overlying coal seam edge, E3S Web Conf 66, 01011 (2018) doi: 10.1051/e3sconf/20186601011

13. J. Kornowski, H. Sokolowski, M. Trombik, A. Wasko, Zasady i zakres stosowania metody wzbudzonej aktywnosci sejsmoakustycznej WAS-96/RMS do oceny stanu zagrozenia tapaniami (The principles and scope of application of the method of induced seismoacoustic activity WAS-96/RMS for the assessment of rock bursts threat) Central Mining Institute, Instrukcje 4, Katowice (1996) (in Polish)

14. Z. Szreder, M. Barnas, Assessment of the impact of an overlying coal seam edge using seismic profiling of refracted P-wave velocity, E3S Web Conf 24, 01007 (2017) doi: $10.1051 / \mathrm{e} 3$ sconf $/ 20172401007$

15. J. Slizowski, Z. Pilecki, K. Urbanczyk, E. Pilecka, L. Lankof, R. Czarny, Adv High Energy Phys, 1-12 (2013) doi: 10.1155/2013/461764 
16. Z. Majcherczyk, Z. Pilecki, E. Niedbalski, E. Pilecka, M. Blajer, J. Pszonka, Wplyw warunkow geologiczno-inzynierskich i geotechnicznych na dobor parametrow obudowy wstepnej tunelu drogowego $w$ Lalikach (Impact of geological, engineering and geotechnical conditions on the selection of parameters of the initial support of the road tunnel in Laliki), Gospod Surowcami Min 28 (1) 103-124 (2012) (in Polish)

17. M. Kudyk, Z. Pilecki, Modul deformacji utworow fliszu karpackiego na trasie tunelu "Emilia" w Beskidzie Zywieckim (Modulus of deformation of Carpathian flysch on the route of the "Emilia" tunnel in the Zywiec Beskids. Zeszyty Naukowe IGSMiE PAN 76, 45-64 (2009) (in Polish).

18. B. Ladanyi, Use of the long-term strength concept in the determination of ground pressure on tunnel linings, Proc. of the $3^{\text {rd }}$ Congress of the Int. Soc. for Rock Mech., II, B, 1150-1156, Denver (1974)

19. Raport 2/2016, Wyniki profilowania sejsmicznego $w$ rejonie chodnika nadscianowego 28a-C3 sciany $28 b$ w pokladzie 510/1 w KWK „Borynia-Zofiowka-Jastrzebie” Ruch Jastrzebie (Report 1/2019 Results of seismic profiling in the gallery 28a-C3 of longwall $28 b$ in the 510/1 coal seam in KWK "Borynia-Zofiowka-Jastrzebie" Ruch Jastrzebie) IGSMiE PAN Krakow, (2019) (in Polish)

20. J. Gustkiewicz (red.), Wlasciwosci fizyczne skal karbonskich gornoslaskiego zaglebia weglowego. Skaly warstw siodlowych (Physical properties of Carboniferous rocks of the Upper Silesian coal basin. Rocks of Saddle beds), Wyd. IGSMiE PAN Krakow (1999) (in Polish)

21. W. Gabzdyl, Charakterystyka petrograficzno-facjalna pokladow wegla $i$ skal towarzyszacych w Kopalni Jastrzebie (Rybnicki Okreg Weglowy) (Petrographic and facial characteristics of coal seams and associated rocks in the Jastrzebie coal mine (Rybnik Coal Area)), Wydawnictwa Geologiczne (1969) (in Polish) 